\title{
The COVID-19 Pandemic and Waste Management
}

\author{
İlhan ÖZTÜRK \\ (D) 0000-0002-6521-0901
}

Çağ University Faculty of Economics and Administrative Sciences, Mersin, Turkey

\author{
COVID-19 Pandemisi ve Atık Yönetimi
}

\section{Corresponding Author Sorumlu Yazar \\ İlhan ÖZTÜRK \\ ilhanozturk@cag.edu.tr}

Received / Geliş Tarihi : 15.01.2021 Accepted / Kabul Tarihi : 08.03.2021 Available Online /

Çevrimiçi Yayın Tarihi : 14.03.2021

\begin{abstract}
Waste management has been a great problem globally for at least five decades. Some of the developed countries could initiated certain processes to benefit from the waste. In this way, countries could both got rid of waste and they could exploit from it and used waste in different ways such as heating, recycling, etc. The situation became even worse during the coronavirus disease 2019 (COVID-19) pandemic. The COVID-19 pandemic has altered global waste generation dynamics and thus became one of the most important issue for all countries for now and for future. Actually, healthcare waste is all the waste generated by healthcare facilities, medical laboratories and biomedical research facilities, as well as waste from minor or scattered sources. However, during the pandemic, masks, increased amounts of contaminated waste including gloves, other protective equipment, and along with non-contaminated materials, many types of additional medical and hazardous waste are produced. These contaminated wastes not only dirts the environment, but also may cause the pandemic spread. The inadequacies and inefficiencies of current waste management system to deal with the increased dependence on plastic could aggravate its mismanagement and leakage into the environment, thus triggering a new environmental crisis. Therefore, this study will highlights the possible effects of COVID-19 on the waste management and environment.

Keywords: COVID-19; waste management; healthcare waste; air pollution; environment.
\end{abstract}

öz

Atık yönetimi sorunu tüm dünyanın en az elli yıldan beri gündeminde olan ve giderek derinleşen bir sorunudur. Kimi gelişmiş ülkeler, atık yönetiminde önemli ilerlemeler kaydetmiş ve atı̆̆ın belli proseslerden geçirilmesinin ardından farklı alanlarda kullanımı ile ekonomik ve yararlı bir ürün haline dönüştürülmesini başarmışlardır. Bu sayede bu ülkeler hem atıktan kurtulmuş hem de ısınma, geri dönüşümlü plastik gibi alanlarda kullanılmışlardır. Atık yönetimi sorunu koronavirüs hastalığı 2019 (coronavirus disease 2019, COVID-19) pandemisi döneminde farklı boyutları ile yönetilmesi daha güç hale gelmiştir. COVID-19 pandemisi, küresel ölçekte atık yönetimi dinamiklerini kökünden değiştirmiş ve bütün ülkelerin günümüzde ve gelecekte en önemli sorunlarından biri haline gelmiştir. Pandemi öncesinde de sağlık hizmetleri dolayısıyla laboratuvar malzemeleri, biyomedikal malzemeler, kitler, iğne ve eldiven gibi atıklar çıkıyordu. Ancak pandemi dönemi ile birlikte maske, kontamine olmuş tıbbi malzemeler, eldivenler, koruyucu malzemeler, tıbbi atık ve tehlikeli atıklar miktar olarak aşırı düzeyde artmıştır. Bu kontamine atıklar, sadece çevreyi kirletmekle kalmaz, hastalığın yayılmasına da yol açar. Pandemi döneminde güçleşen atık yönetimindeki yetersizlik ve plastik ürünlere olan bağımlılığın daha fazla artması, bunların çevreye daha fazla atılmasına, çevrenin pandemi öncesine göre daha fazla kirlenmesine ve yeni çevre felaketlerinin tetiklenmesine yol açabilir. $\mathrm{Bu}$ çerçevede, bu çalışmada COVID-19 pandemisinin korunma tedbirleri kapsamında artan çevreyi kirletici tıbbi malzeme kullanımı dolayısıyla atık yönetimi ve çevre üzerinde oluşturduğu olumsuz etkiler incelenecektir.

Anahtar kelimeler: COVID-19; atık yönetimi; tıbbi atıklar; hava kirliliği; çevre. 
All through the history of mankind, there have been a few huge flare-ups of irresistible illnesses, and the passing toll of these illnesses is comparable to numbers of lives misplaced in wars. Inside the 20 years of the $21^{\text {st }}$ century, there have been numbers of huge scourges, such as severe acute respiratory syndrome (SARS), H7N9, Zika, Ebola, and presently coronavirus disease 2019 (COVID-19). The current battle against the novel coronavirus isn't as it were a weight test of World's in general therapeutic framework, but moreover an extreme challenge to each clinic across the country, particularly in open wellbeing crisis distinguishing proof speed, crisis administration capacity, and the capacity to save and disseminate supplies (1).

From the initial time in history, a wellbeing crisis has closed down the whole worldwide economy, agonizingly illustrating how indivisible healthcare and the economy have ended up.

The COVID-19 pandemic and administrative arrangements to contain the spread of infection have caused a worldwide financial subsidence and have too produced a gigantic sum of restorative squander. The affect of COVID-19 is changing the way we live, from one day to the following. Whereas national and nearby intercessions are generally centered on securing lives and economies, administration of dangerous squander is additionally basic to play down long-term dangers to human and natural wellbeing. Since the flare-up of COVID-19, medical squander era is expanded all inclusive, which could be a major danger to open wellbeing and environment. For test collection of the suspected COVID-19 patients, determination, treatment of tremendous number of patients, and sanitization reason parts of irresistible and biomedical squanders are created from clinics (2).

Healthcare waste is all the waste generated by healthcare facilities, medical laboratories and biomedical research facilities, as well as waste from minor or scattered sources. The inadequacies and inefficiencies of current waste management system to deal with the increased dependence on plastic could aggravate its mismanagement and leakage into the environment, thus triggering a new environmental crisis. The viral pandemic has produced both positive and negative indirect effects on the environment.

In spite of several negative effects of COVID-19 as shown in Figure 1, it has been reported in many studies that the reduction in economic activities due to COVID-19 significantly improves the air quality in different cities of the world, reduces greenhouse gas emissions, water pollution and noise. In other words, in spite of the negative aspects of coronavirus on the globe, the coronavirus crises brought a positive impact on the natural environment. In addition, several recent studies also indicated that this COVID-19-induced lockdown has reduced the environmental pollution drastically worldwide. For example, in China, emissions of harmful gases and other pollutants dropped $25 \%$ at the start of the year 2020 and the quality of air improved up to $11.4 \%$ with respect to start of the last year, in 337 cities across China (3).

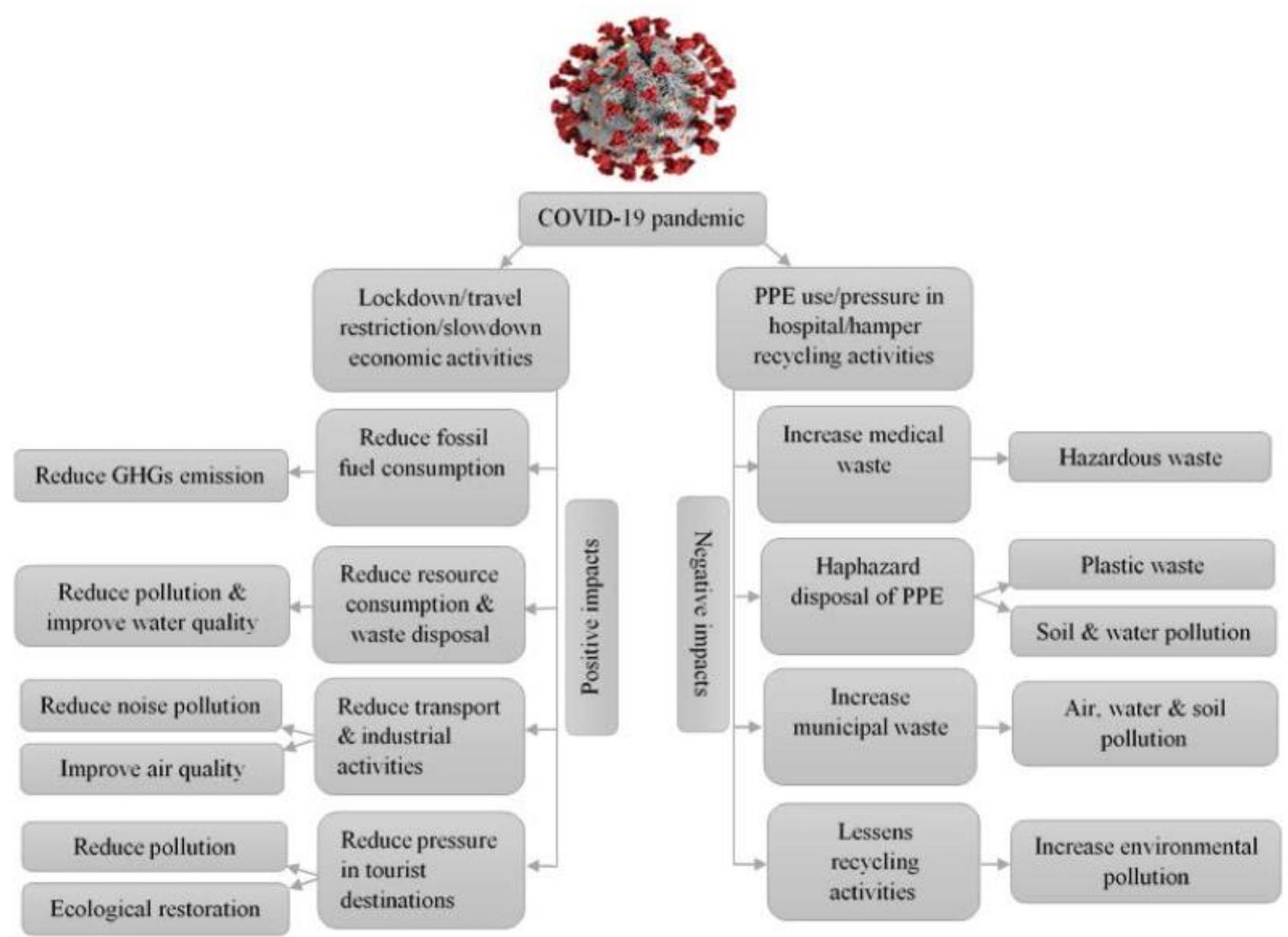

Figure 1. Positive and negative environmental effects of COVID-19 pandemic. Source: Rume and Islam (4). 
According to a European Environment Agency (EEA), the COVID-19 pandemic and resulting restrictions imposed to fight the spread of the disease have provided some shortterm positive impacts on Europe's environment, such as improvements in air quality, lower greenhouse gas emissions and lower levels of noise pollution. However, the EEA also stresses that there have been negative consequences such as increased use of single-use plastics and medical waste during the same period. Similarly, in the USA, an increase in garbage production from personal protective equipment has been recorded. The problem got worse, after many countries particularly the USA and the European nations have stopped waste recycling programs in some of their cities, concerning the risk of COVID-19 spreading in the recycling centers (5).

The utilize of expendable plastic-based individual defensive gear (PPEs) and single-use plastics amid the widespread not as it were increments the amount of restorative squander but too changes the normal thickness of the therapeutic squander. Squander era in the midst of COVID-19, particularly disposed of PPEs and single-use plastics, has been a natural and open wellbeing emergency around the world especially within the nations with creating economies and those in move.

The current quick surge in healthcare squander due to the COVID-19 pandemic is advance compounding the issue and there's a prompt danger that the impacts of hazardous transfer of healthcare squander will spill over into an emergency of natural contamination. Hazardous transfer of healthcare squander not as it were contaminates the environment but moreover conduces to the spread of irresistible illnesses such as Hepatitis, HIV/AIDS, cholera, typhoid and respiratory complications, which are primarily caused by the reusing of the transfer restorative gear or by rummaging the restorative waste, as detailed completely different nations (2). During such an epidemic, masks, increased amounts of contaminated waste including gloves, other protective equipment, and along with noncontaminated materials, many types of additional medical and hazardous waste are produced. For example, in Wuhan, the center of the epidemic in China, six times more medical waste is produced.

Masks, gloves and protective gowns, which are the main defense tools in the fight against coronavirus and protection, are turning into a growing waste problem worldwide. Uncollected waste, after being dragged by winds and rains, can enter the sewer and enter the water, exacerbating the already large plastic waste problem worldwide.

To reduce the burden of wastes and environmental pollution, both industrial and municipal wastes should be recycled and reused. Moreover, hazardous and infectious medical waste should be properly managed by municipal and hospitals. Therefore, proper strategies should be adopted to control environmental degradation and wastes.

Ethics Committee Approval: Since our study was a review, ethics committee approval was not required.

Conflict of Interest: None declared by the authors.

Financial Disclosure: None declared by the authors.

Acknowledgements: None declared by the authors.

Author Contributions: Idea/Concept: İÖ; Design: İÖ; Data Collection/Processing: İÖ; Analysis/Interpretation: İÖ; Literature Review: İÖ; Drafting/Writing: İÖ; Critical Review: İÖ.

\section{REFERENCES}

1. deloitte.com [Internet]. Deloitte. Thoughts on healthcare management in an epidemic. [Cited: 2021 Mar 08]. Available from: https://www2.deloitte.com/cn/en/pages/risk/articles/th oughts-on-construction-of-large-health-managementsystem-under-2019-ncov.html

2. Singh N, Tang Y, Zhang Z, Zheng C. COVID-19 waste management: Effective and successful measures in Wuhan, China. Resour Conserv Recycl. 2020;163:105071.

3. who.int [Internet]. World Health Organization. Air pollution. [Cited: 2021 Mar 08]. Available from: https://www.who.int/health-topics/air-pollution

4. Rume T, Islam SMD. (2020). Environmental effects of COVID-19 pandemic and potential strategies of sustainability. Heliyon. 2020;6(9):e04965.

5. Zambrano-Monserrate MA, Ruano MA, SanchezAlcalde L. (2020). Indirect effects of COVID-19 on the environment. Sci Total Environ. 2020;728:138813.

6. unep.org [Internet]. UNEP. UN environment programme. [Cited: 2021 Mar 08]. Available from: https://www.unep.org 